\title{
Environmental conditions to support blue carbon storage in mangrove forest: A case study in the mangrove forest, Nusa Lembongan, Bali, Indonesia
}

\author{
CINDY CLARA PRICILLIA ${ }^{1, \vartheta}$, MUFTI PETALA PATRIA ${ }^{1,2}$, HERDIS HERDIANSYAH $^{1, \vee \vartheta}$ \\ ${ }^{1}$ School of Environmental Science, Universitas Indonesia. Jl. Salemba Raya No. 4, Campus of UI Salemba, Kenari sub-district, Senen district, Central \\ Jakarta 10430, Jakarta, Indonesia. Tel./fax. \{+62-21 31930251, ”email: cindyclarap@gmail.com \\ ${ }^{2}$ Department of Biology, Faculty of Mathematics and Natural Sciences, Universitas Indonesia. Jl. Prof. Soedjono D. Poesponegoro (Lingkar Kampus \\ Raya), Pondok Cina, Beji, Depok 16424, West Java, Indonesia. Tel./fax.:+62-21-7270163, “vemail: herdis@ui.ac.id
}

Manuscript received: 6 April 2021. Revision accepted: 23 May 2021

\begin{abstract}
Pricillia CC, Patria MP, Herdiansyah H. 2021. Environmental conditions to support blue carbon storage in mangrove forest: A case study in the mangrove forest, Nusa Lembongan, Bali, Indonesia. Biodiversitas 22: 3304-3314. Mangrove ecosystems can provide ecosystem services to mitigate climate change by absorbing and storing carbon in their systems. The question arises of how to manage a mangrove forest to store more carbon. The Nusa Lembongan mangrove forest was examined to assess the optimal environmental settings for blue carbon storage in the mangrove ecosystem. Five stations were selected purposively. The parameters observed in each station were aboveground living biomass, mangrove stand density, clay percentage in soil, bulk density, water content, soil organic carbon $(\% \mathrm{C})$, and soil organic nitrogen $(\% \mathrm{~N})$. Based on this study, the total carbon stock in mangrove forest Nusa Lembongan was $68.10 \pm 20.92 \mathrm{Mg} \mathrm{C}^{-1}$ and equals to $249.95 \pm 76.77 \mathrm{MgCO}_{2} \mathrm{ha}^{-1}$ with a significant contribution of soil carbon stock. This study indicates that the essential parameters that can promote carbon sequestration in mangrove forest Nusa Lembongan were aboveground living biomass, soil organic carbon content and soil organic nitrogen content. In addition, as soil organic carbon content also negatively correlates with bulk density, it also can be considered. These findings can contribute to blue carbon planning and management to improve the effectiveness of the blue carbon project.
\end{abstract}

Keywords: Aboveground biomass, blue carbon, climate change, mangrove, soil organic carbon

Abbreviations: AA: Avicennia alba, AM: Avicennia marina, AMR: Avicennia marina var. rumphiana, BC: Bruguiera cylindrica, BG: Bruguiera gymnorhiza, CT: Ceriops tagal, DBH: Diameter at breast height, NDC: Nationally Determined Contributions, RA: Rhizophora apiculata, RM: Rhizophora mucronata, RS: Rhizophora stylosa, SA: Sonneratia alba, UNFCCC: United Nations Framework Convention on Climate Change, XG: Xylocarpus granatum

\section{INTRODUCTION}

The stored carbon in coastal ecosystems is called blue carbon (Macreadie et al. 2019). The term has been emerging since 2009 as a concern of coastal ecosystem degradation and a considerable contribution to global carbon sequestration (Lovelock and Duarte 2019; Macreadie et al. 2019). In particular, mangrove ecosystems have been degrading at an alarming rate, from 1 to $8 \%$ per year (Friess et al. 2019). Simultaneously, mangrove's ability to sequester carbon is generally higher than terrestrial and coastal vegetation at the local plot scale (Grace et al. 2006; Lewis et al. 2009; Estrada and Soares 2017; Taillardat et al. 2018). Nevertheless, blue carbon only accounts for $1.3 \%$ of land carbon sink globally because of lower coverage area (Taillardat et al. 2018). As a response to this matter, the United Nations Framework Convention on Climate Change (UNFCCC) promotes the integration of mangrove ecosystems in Nationally Determined Contributions (NDC) as the mitigation plan, besides adaptation plan. Taillardat et al. (2018) argue that including mangroves as a climate change mitigation strategy is most effective at the national level. Understanding the factors that influence carbon burial in mangrove ecosystems can contribute to effective planning and climate change mitigation plans.

Globally mangrove ecosystem has a total carbon stock of $738 \pm 27.9 \mathrm{Mg} \mathrm{C} \mathrm{ha}^{-1}$ of which $77 \%$ of the carbon is stored in soil (Alongi 2020). Although mangrove forests in the world only account for $0.2 \%$ of terrestrial vegetation coverage (Hamilton and Casey 2016), in a country that has extensive mangrove area, it is essential to consider the mangrove ecosystem as a mitigation plan. Given this matter, the Indonesian government has been starting to incorporate mangrove ecosystems by including mangrove forests in National Greenhouse Gas Inventory. However, carbon stored in mangrove soil has not been included yet (Anwar 2020). Studies that address carbon stock in mangrove soil are urgently needed to improve data availability and reduce uncertainty. Moreover, it is also suggested to provide local-scale mangrove data to increase data accuracy and enable high-resolution data. Hence, it could help address conservation challenges in various geographic settings (Worthington et al. 2020). 
According to Howard et al. (2017), prioritizing areas that have high carbon sequestration potential for blue carbon projects is essential. Nevertheless, studies regarding the factors that influence carbon storage in the mangrove ecosystem are scarce, including which species and geography significantly impact carbon storage (McLeod et al. 2011; Howard et al. 2017). Few studies have observed the factors that influence carbon preservation in mangrove ecosystem (Matsui et al. 2015; Weiss et al. 2016; Martuti et al. 2017; Asadi et al. 2018; Pérez et al. 2018; Gao et al. 2019; Kida and Fujitake 2020). Findings of these studies showed that the influencing factors of carbon sequestration in the mangrove ecosystem were varied and complicated. Hence quantitative analysis of influencing factors that promote carbon preservation is necessary for different geographic settings (Huang et al. 2018). This study analyzed seven parameters: aboveground living biomass, mangrove stand density, clay percentage in soil, bulk density, water content, soil organic carbon $(\% \mathrm{C})$, and soil organic nitrogen $(\% \mathrm{~N})$. These parameters were analyzed to determine which parameters will significantly correlate with the mangrove ecosystem's total carbon stock. These parameters will preview suitable geographical settings for carbon storage at a local scale project. It also will reveal which species have the potential to store more carbon for further rehabilitation efforts.

Hence, to understand the correlation between those parameters, the mangrove forest in Nusa Lembongan was selected as the research location. It has a high-density mangrove forest and has been protected under the regulation of the Ministry of Environment and Forestry of
The Republic of Indonesia since 1981. The mangrove ecosystem in the mangrove forest Nusa Lembongan can store carbon in biomass of $90.72 \mathrm{Mg} \mathrm{C} \mathrm{ha}^{-1}$ (Kusumaningtyas et al. 2014). However, the previous study had not included soil carbon stock. As far as the authors determine, no study has been done regarding carbon storage ability in mangrove soils in the mangrove forest Nusa Lembongan. This study can contribute to the planning and management of mangrove ecosystems, as these forests are often chosen as locations for mangrove rehabilitation programs.

\section{MATERIALS AND METHODS}

\section{Study area}

The mangrove forest of Nusa Lembongan is located on the south of Bali mainland, lying between latitude $115^{\circ} 27^{\prime} 0^{\prime \prime}$ E-115 28'23.1" E and longitude $8^{\circ} 39^{\prime} 51.2^{\prime \prime} \mathrm{S}-$ $8^{\circ} 41 ' 37.8^{\prime \prime} \mathrm{S}$ (Figure 1). It covers a total of 202 ha (Palguna et al. 2017). In the mangrove forests of Nusa Lembongan, six families were found, namely Acanthaceae, Avicenniaceae, Lythraceae, Rhizophoraceae, Meliaceae, Euphorbiaceae and Combretaceae (Palguna et al. 2017). Distribution of mangrove species in mangrove forest of Nusa Lembongan does not form a distinctive zonation; however, the exposed mangrove zone was dominated with Rhizophora stylosa Griff., Rhizophora apiculata Blume and Sonneratia alba Sm. (Welly et al. 2010). In this study, five stations were selected purposively to represent the mangrove area's various environmental settings.

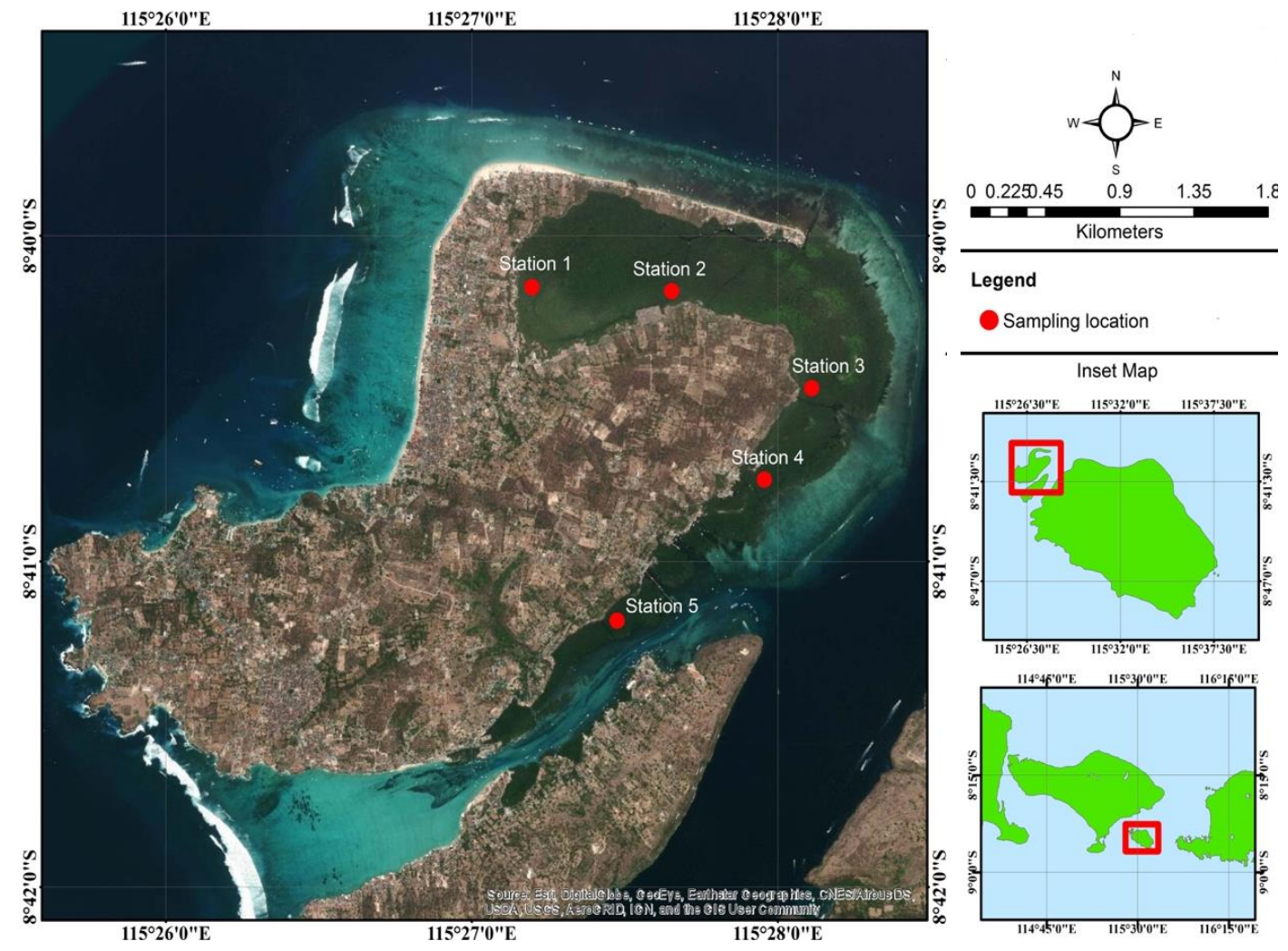

Figure 1. Location of sampling site in mangrove forest of Nusa Lembongan, Bali Province, Indonesia 
Here, brief information about each station is explained based on the author's observation. Station 1 is located in $8^{\circ} 40^{\prime} 06.5$ "S $115^{\circ} 27^{\prime} 15.2^{\prime \prime} \mathrm{E}$, which is far from offshore, adjacent to the housing complex, and characterized by minimal active disturbance. At the time of the study, crab and cockle collectors were not found. However, based on local people's information, sometimes people get inside to collect crabs and cockles. Station 2 is located in $8^{\circ} 40^{\prime} 04.9^{\prime \prime}$ $\mathrm{S}, 115^{\circ} 27^{\prime} 36.3^{\prime \prime} \mathrm{E}$, which adjacent to the landfill with minimal disturbance. Station 3 is located in $8^{\circ} 40^{\prime} 16.7^{\prime \prime} \mathrm{S}$, $115^{\circ} 28^{\prime} 09.4^{\prime \prime} \mathrm{E}$; based on local people information, almost no one enters this area because of the high density of mangrove, dominated with Rhizophora sp. which had high and dense stilt-roots making it almost inaccessible. Station 4 is located in $8^{\circ} 40^{\prime} 44.0^{\prime \prime} \mathrm{S} 115^{\circ} 27^{\prime} 57.3^{\prime \prime} \mathrm{E}$; unlike other stations far from offshore exposure and characterized with clay-dominated soil, this station is directly facing the offshore and had soil mixed between sand and clay. This station is also the site for mangrove tours. Station 5 is located in $8^{\circ} 41^{\prime} 10.1^{\prime \prime} \mathrm{S}, 115^{\circ} 27^{\prime} 29.5^{\prime \prime} \mathrm{E}$, adjacent to offshore and had soil mixed between sand and clay. This station also had a high density of mangrove; and it was almost inaccessible because of the stilt-roots of Rhizophora sp. As observed, water salinity in stations 1, 2, 3, 4, and 5 were $25 \mathrm{ppt}, 28 \mathrm{ppt}, 26 \mathrm{ppt}, 31 \mathrm{ppt}$ and $31 \mathrm{ppt}$ respectively.

\section{Procedures}

\section{Data collection}

Data collection in the mangrove ecosystem was carried out at five stations, according to Figure 1. At each station, two $100 \mathrm{~m}$ transects were laid from the shore perpendicular towards the mangrove forest, the distance between transects was $50 \mathrm{~m}$. Square plots sized $10 \times 10 \mathrm{~m}$ were set along the transect in $35 \mathrm{~m}$ intervals ( 6 plots in total). The stands were distinguished between trees, saplings, and seedlings. Tree characterized with diameter at breast height $(\mathrm{DBH}) \geq 10 \mathrm{~cm}$ and height of $\geq 1.5 \mathrm{~m}$; sapling has $\mathrm{DBH}<$

$10 \mathrm{~cm}$ and height of $\geq 1.5 \mathrm{~m}$; and seedling has height $\geq 1.5$ $\mathrm{m}$ (Soerianegara and Indrawan 1988). However, based on our observation, all quadrats are dominated by the sapling. Considering that, the sapling has to be accounted for aboveground living biomass carbon stock (Lovelock et al. 2005). In contrast, the seedling will be neglected from aboveground living biomass carbon stock quantification due to insignificance contribution in carbon content (Kauffman and Donato 2012). Therefore to determine the number of stands in each quadrat, an area plot of $10 \times 10 \mathrm{~m}$ was used to determine the number of trees and saplings to increase DBH measurement accuracy. However, smaller plots sized $2 \times 2 \mathrm{~m}$ were used to determine the number of seedlings.

The observed in-situ parameters were the number of stands, species, DBH, and water salinity. Soil samples were collected using stainless steel core having $30 \mathrm{~cm}$ length and $7 \mathrm{~cm}$ diameter in three selected plots in each station. The later sample was separated into $0-15 \mathrm{~cm}$ and $15-30 \mathrm{~cm}$ depth. The subsampling strategy was carried out following method of Howard et al. (2014). During soil sample collection, core compression occurred; therefore, the compaction correction factor was used to determine soil subsampling depth (Howard et al. 2014). The compaction correction factor was calculated by dividing the length of soil extracted from the core and the length of core penetration. Then, the result was multiplied with the desired depth. The subsamples were placed in Zip-lock plastic bags and labeled. The soil samples were preserved in a freezer $\left(<4^{\circ} \mathrm{C}\right)$ until further laboratory analysis.

Besides soil samples, tree biomass was also collected for carbon stock estimation. For each species that were identified in the mangrove forest, two samples of branches were collected. At the time of the study, eleven species were found: Xylocarpus granatum J. Koenig., Ceriops tagal (Perr.) C.B. Rob., S. alba, Rhizophora mucronata Lam., R. apiculata, R. stylosa, Avicennia marina (Forssk.) Vierh., Avicennia marina var. rumphiana (Hallier f.) Bakh., Avicennia alba Blume., Bruguiera cylindrica (Linnaeus) Blume. and Bruguiera gymnorhiza (L.) Lam. Due to customary law applied in the mangrove forest, which prohibited cutting down mangrove trees, authorities (Perbekel Jungutbatu Village and local government) approved collecting samples in a limited number.

Mangrove ecosystem condition

Parameters used as an indicator for mangrove ecosystem conditions were aboveground biomass, mangrove density, clay percentage in soil, bulk density, moisture content, and $\mathrm{C}: \mathrm{N}$ ratio. After obtaining the number of stands and species, the mangrove density was determined using the equation of (Bengen 2000).

$$
D i=\frac{n i}{A}
$$

Where: $\mathrm{Di}$ is the mangrove density of species $\mathrm{i}$ (ind $\mathrm{m}^{-}$ ${ }^{2}$ ), $\mathrm{Ni}$ is the number of stands of species $\mathrm{i}$ (ind), and $\mathrm{A}$ is area $\left(\mathrm{m}^{2}\right)$. The analyzed samples consisted of soil and biomass. Aboveground biomass was obtained from wood density and DBH values using the allometric equations specified for each species (Howard et al. 2014). The branch samples were cut into $2.5 \mathrm{~cm}$ long pieces; the number of cut samples from each branch was $\mathrm{n}=25$. Then, samples were measured for volume using Archimedes principles. The samples' dry weight was measured after they were dried in oven at $100^{\circ} \mathrm{C}$ until constant weight. Wood density was calculated by dividing dry weight samples and the volume of samples. Later, the following allometric equations were used to determine aboveground biomass for specified species (Table 1), where variables used are wood density $(\rho)$ and DBH.

Biomass of each tree in quadrate plot was estimated using an allometric equation. Later, all of the aboveground biomass were summed up and converted into $\mathrm{Mg} \mathrm{ha}^{-1}$. Clay percentage was obtained from the pipetting method (Tan 2005). Bulk density was obtained using the disturbed soil method following Tan (2005) due to soil compaction that may lead to soil volume bias. The procedure started with a weighted $100 \mathrm{ml}$ graduated cylinder, then the cylinder was 
filled with $<2 \mathrm{~mm}$ of soil. The first addition of soil was compacted by tapping the cylinder base ten times with the palm. The soil was kept added until $100 \mathrm{ml}$ of soil volume was achieved, then the soil cylinder was weighed. The procedures were repeated twice for the average value. Soil moisture content was analyzed separately; $10 \mathrm{~g}$ of moist soils were dried using in oven at $105^{\circ} \mathrm{C}$ for 24 hours (Tan 2005). The weight difference between wet soil and ovendried soil was taken as soil moisture content (Tan 2005). The bulk density was calculated using the equation following (Tan 2005).

$$
\begin{aligned}
& \text { Oven-dry weight of soil } \frac{\text { (weight of } 100 \mathrm{ml} \text { sample of air-dry soil } \times 100)}{100+\text { soil mosture content }} \\
& \text { Bulk Density }=\frac{\text { owen-dry weight of } 100 \mathrm{ml} \text { soil }}{100}\left(\mathrm{~g} \mathrm{~cm}^{-3}\right)
\end{aligned}
$$

Where: $\mathrm{C}: \mathrm{N}$ ratio was obtained from organic carbon content and organic nitrogen content ratio. Organic carbon content was analyzed using Walkley and Black method (American Society of Agronomy and Soil Science Society 1982), while organic nitrogen content was determined using the Kjeldahl method (American Society of Agronomy and Soil Science Society 1982).

\section{Carbon stock}

Carbon stock sampling was carried out on the biomass and soil of mangrove ecosystems. Soil samples were prepared for analysis by oven-drying at $35^{\circ} \mathrm{C}$, powdered, and sieved with $2 \mathrm{~mm}$ sieve. Afterward, organic carbon content was analyzed using the Walkley and Black method to determine organic carbon concentration. The following formula was used to calculate carbon stock in soils (Howard et al. 2014).

$$
C t=\left(\frac{\% \operatorname{Corg}}{100}\right) x \rho x d
$$

Where: $\mathrm{Ct}$ is total carbon stock in soils $\left(\mathrm{g} \mathrm{cm}^{-2}\right), \mathrm{d}$ is soil interval $(\mathrm{cm}) ; \rho$ is a ratio of dry weight $(\mathrm{g})$ and sample volume $\left(\mathrm{cm}^{3}\right)$, and \%Corg is organic carbon content from laboratory analysis. After this, carbon stock data were tabulated based on depth. To determine total carbon stock in a single core, carbon stock value in $0-15 \mathrm{~cm}$ depth was summed up with carbon stock value in $15-30 \mathrm{~cm}$ depth. The results were converted into $\mathrm{Mg} \mathrm{C}$ ha $^{-1}$ with the following equation (Howard et al. 2014)

$$
\text { Corg }\left(\frac{M g C}{h a}\right)=\text { Corg in a single core }\left(\frac{g}{\mathrm{~cm}^{2}}\right) \times \frac{1 \mathrm{Mg}}{1.000 .000} g \times \frac{100.000 .000 \mathrm{~cm}^{2}}{1 \mathrm{ha}}
$$

The calculation was repeated for all coring, and calculations for other cores in a given station using the equation below to determine organic carbon stored in mangrove soil in the study area.

$$
\bar{X}=\frac{(\text { Corg core } \# 1+\text { Corg core } \# 2+\cdots \mathrm{n})}{n} \pm \sigma
$$

Where: $\bar{X}$ is the average of carbon stock in all coring, $\mathrm{n}$ is the total number of all coring, and $\sigma$ is standard deviation. Then the following formula to determine the concentration of organic carbon in biomass (Howard et al. 2014).

$$
C_{a b q}=\rho \times 0.46
$$

Where: $\mathrm{C}_{\mathrm{abg}}$ is carbon stock in aboveground biomass, $\rho$ is aboveground biomass $\left(\mathrm{Mg} \mathrm{ha}^{-1}\right), 0.46$ is the conversion factor. Eventually, to measure the total carbon stock in each station, which consists of aboveground biomass and soils, each pool's carbon stock was summed up.

\section{Data analysis}

The results of sample processing in the laboratory were tabulated, and then using the SPSS application, the data was processed for descriptive statistical analysis. Determination of optimal mangrove conditions for blue carbon storage was carried out by analyzing mangrove forest conditions consisting of aboveground biomass, mangrove stand density, clay percentage in soil, bulk density, water content, and $\% \mathrm{~N}$ and its association with carbon stock in biomass and soils. The influence of each factor was determined using multiple regression analysis

\begin{tabular}{|c|c|c|c|}
\hline Species & Study sites & Allometric equation & Source \\
\hline$X$. granatum & Asia & $\mathrm{W}=0.251 \rho(\mathrm{DBH})^{2.46}$ & Komiyama et al. (2005) \\
\hline C. tagal & South Sulawesi, Indonesia & $\mathrm{W}=0.529 \mathrm{DBH}^{2.04}$ & Kangkuso et al. (2018) \\
\hline Sonneratia spp. & Central Jawa, Indonesia & $\mathrm{W}=0.258 \mathrm{DBH}^{2.287}$ & Kusmana et al. (2018) \\
\hline R. mucronata & South Sulawesi, Indonesia & $\mathrm{W}=0.143 \mathrm{DBH}^{2.52}$ & Kangkuso et al. (2018) \\
\hline R. apiculata & South Sulawesi, Indonesia & $\mathrm{W}=0.268 \mathrm{DBH}^{2.345}$ & Kangkuso et al. (2018) \\
\hline R. stylosa & Phillipines & $\mathrm{W}=0.045 \mathrm{DBH}^{2.868}$ & Gevana and Im (2016) \\
\hline A. marina & Australia & $\mathrm{W}=0.308 \mathrm{DBH}^{2.11}$ & Comley and McGuinness (2005) \\
\hline A. marina var. rumphiana & Asia & $\mathrm{W}=0.251 \rho(\mathrm{DBH})^{2.46}$ & Komiyama et al. (2005) \\
\hline A. alba & Asia & $\mathrm{W}=0.251 \rho(\mathrm{DBH})^{2.46}$ & Komiyama et al. (2005) \\
\hline B. gymnorhiza & Australia & $\mathrm{W}=0.186 \mathrm{DBH}^{2.31}$ & Clough and Scott (1989) \\
\hline B. cylindrica & Asia & $\mathrm{W}=0.251 \rho(\mathrm{DBH})^{2.46}$ & Komiyama et al. (2005) \\
\hline
\end{tabular}
using SPSS. For complete results in all mangrove forest areas, the satellite image was used to determine the level of mangrove vegetation health using the normalized difference vegetation index (NDVI) method.

Table 1. Allometric equation for calculating aboveground biomass 
The software used to process satellite images is QGIS. The data used was a $10 \times 10 \mathrm{~m}$ resolution Sentinel 2 satellite image extracted from Copernicus Open Access Hub. This study used the satellite image from February 27th, 2020. NDVI is used to determine mangroves' classification based on an index indicating the presence of green plants and a vegetation health index by utilizing a combination of the Near-Infrared (NIR) band from a satellite image (Daulat et al. 2018). NDVI values range between -1 and +1 , and positive values mean high vegetation quantity, and negative values indicate the absence of vegetation (Mather and Koch 2011). Vegetation reflecting the combination of the visible red wave spectrum and the NIR wave spectrum (Daulat et al. 2018). Healthy vegetation will absorb most of the incoming red waves and reflect most of the NIR waves. The opposite applies to unhealthy vegetation, which is mathematically understood by the following equation (Daulat et al. 2018).

$$
N D V I=\frac{(N I R-R e d)}{(N I R+R e d)}
$$

Where: NDVI is the normalized difference vegetation index, NIR is the near-Infrared band, and Red is the red band. After obtaining data on the mangrove ecosystem's community structure at each station and satellite image processing, the two data were compared to validate general density levels for the mangrove ecosystem in the mangrove forest at Nusa Lembongan.

\section{RESULTS AND DISCUSSION}

\section{Mangrove stand density}

Mangrove stand density can affect carbon stock and the rate of carbon accumulation; the more standing mangroves, the more carbon can be absorbed and stored in the area (Suryono et al. 2018). High stand density can slow down the flow/turbulence in the area; hence mangrove litter can be directly deposited in the soil. The sedimentation rate of solid particles is also higher than in areas with high currents (Breithaupt et al. 2012; Barreto et al. 2016). This study found 10 species and a variety, while the most cited publication to determine mangrove species in Nusa Lembongan found 13 species (Welly et al. 2010). Figure 2 presents the result of mangrove stand density. Based on the observation, sapling dominates in all of the mangrove stations. Hence, to improve the discussion's clarity, this study will indicate mangrove density as the total of trees and saplings. Figure 2 shows mangrove density in each station In general, the average mangrove density in all of the stations was $4940 \pm 1710.33$ ind $\mathrm{ha}^{-1}$; this study found a higher density than the previous study, which was 3044.4 ind ha $^{-1}$ (Kusumaningtyas et al. 2014). Plants of $R$. mucronata and $R$. apiculata were found in all stations. The abundance distribution of $R$. mucronata and $R$. apiculata shows high tolerance of these species in various geographical settings, which differs by salinity, tidal exposure and soil.

Based on Figure 2, it was known that the highest mangrove density was found in station 2 , which is dominated by $R$. mucronata. Station 2 was located directly adjacent to the landfill, but it was assumed that it does not reduce mangrove density. However, the total number of tree densities in station 2 was the lowest compared to other stations with 400 trees $\mathrm{ha}^{-1}$, while other stations had more than 550 trees $\mathrm{ha}^{-1}$, station 2 was dominated by the young stand with $\mathrm{DBH}<10 \mathrm{~cm}$. It can be assumed that the leachate from landfills may contaminated mangrove soil because at the time of the study, leachates were not treated before they reached the mangrove forest. Leachate from municipal solid waste open dumping site usually contains heavy metals, namely, $\mathrm{Mn}, \mathrm{Pb}, \mathrm{Cu}, \mathrm{Cd}, \mathrm{Cr}$ and $\mathrm{Ni}$ (Kanmani and Gandhimathi 2013; Ishchenko 2018). A high-level concentration of $\mathrm{Cr}, \mathrm{Cu}$ and $\mathrm{Ni}$ can decline mangrove growth if the heavy metals concentration absorbed in mangrove biomass exceeds its limit (Nguyen et al. 2020). The lowest mangrove density was found in station 1 , which was located adjacent to settlements.

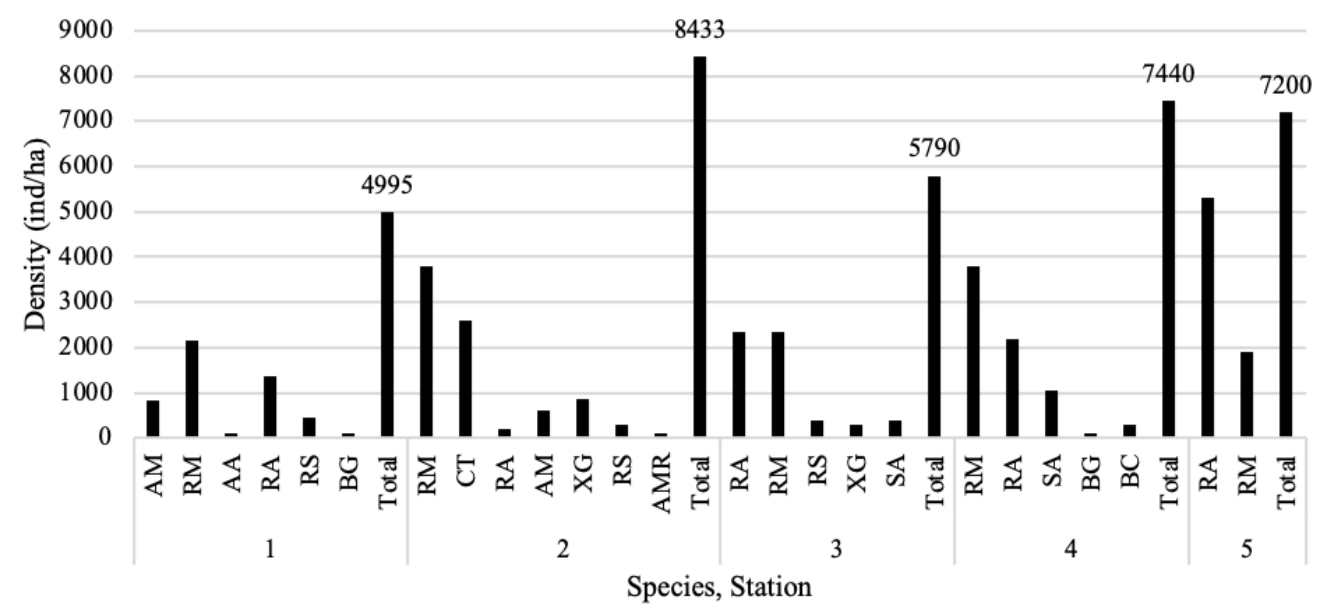

Figure 2. Mangrove density (total density of trees and saplings) in Nusa Lembongan, Bali Province, Indonesia. Note: $A$. alba (AA), $A$. marina var. rumphiana (AMR), A. marina (AM), B. cylindrica (BC), B. gymnorhiza (BG), C. tagal (CT), R. apiculata (RA), R. mucronata (RM), R. stylosa (RS), S. alba (SA), X. granatum $(\mathrm{XG})$ 

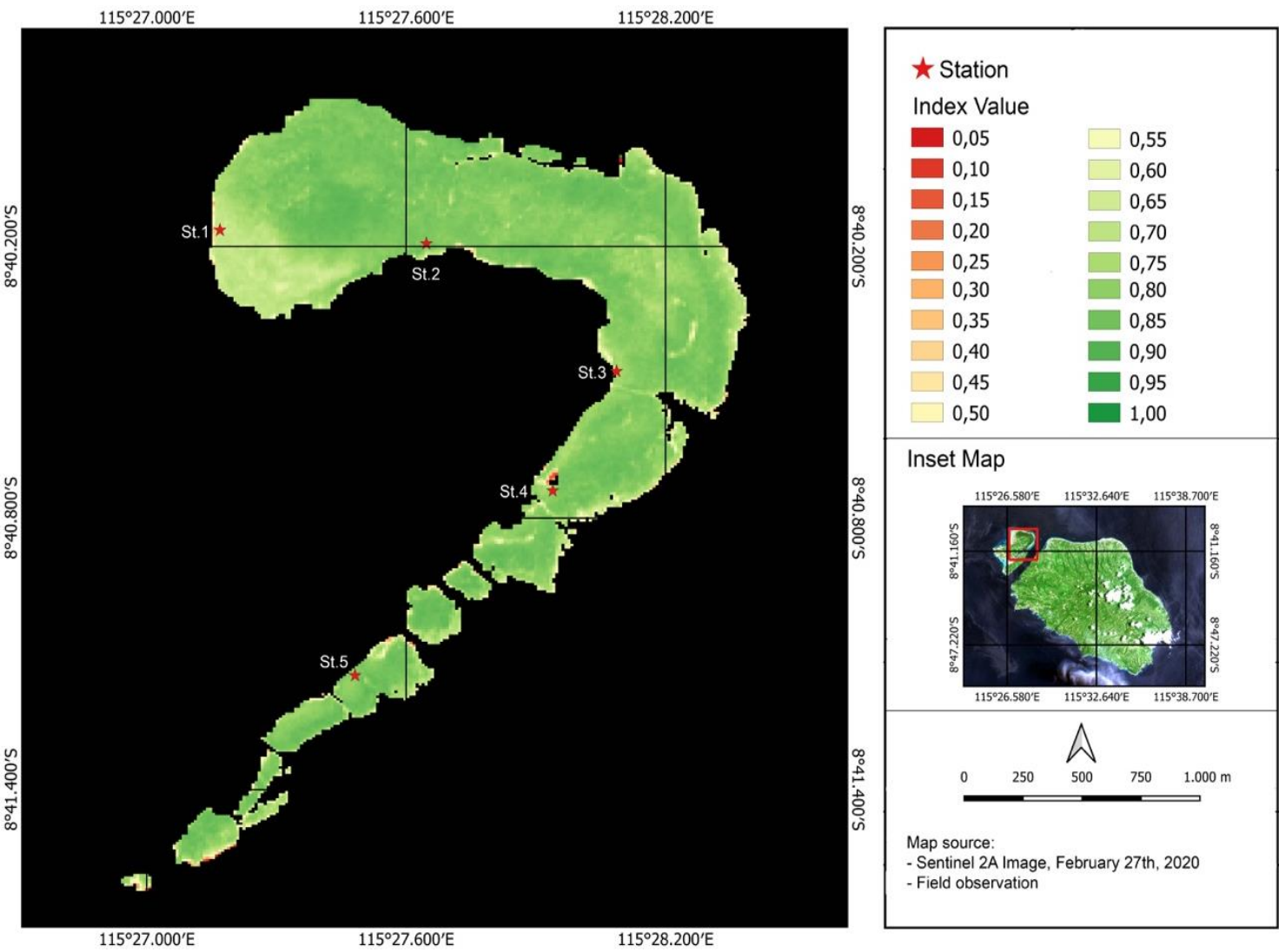

Figure 3. NDVI of mangrove forest in Nusa Lembongan, Bali Province, Indonesia

For complete determination of all mangrove forest areas, the satellite image was used to determine the level of mangrove vegetation health using the NDVI method. Figure 3 shows the processed image.

This study found that the NDVI value ranged from 0.670 to 0.896 , with an average index of $0.798 \pm 0.074$. Previously, Daulat et al. (2018) used similar method to determine mangrove health in Nusa Lembongan for 2003, 2010, and 2017 which had an average index of 0.773 , 0.763 , and 0.821 , respectively. This study has a higher average index than the years 2003 and 2010 but lower to the year 2017; indicating reduction in mangrove canopy coverage because of a reduction in mangrove density. The previous study argues a significant relationship between NDVI value and mangrove stand density (Satyanarayana et al. 2011). This study also shows that the same results after a simple regression analysis were conducted, resulting in $\mathrm{R}^{2}=0.377$ and $\mathrm{p}<0.05$. The average NDVI value for individuals stations in this study were $0.628,0.843,0.795$, 0.819 and 0.830 in stations $1,2,3,4$ and 5 respectively. Based on the field data, the highest to the lowest mangrove density were in stations $2,5,4,3$ and 1 ; compared to NDVI, it presents the same result. The coverage area of mangrove forests was 203.67 ha which is greater than the report of Palguna et al. (2017). Later, the result of NDVI values were classified into three categories of mangrove coverage area according to Indonesia Forestry Department (2005) viz. rare, moderate and dense, as showed in Table 2.
Table 2. Classification of mangrove coverage in mangrove forest Nusa Lembongan, Bali Province, Indonesia based on NDVI analysis

\begin{tabular}{lcc}
\hline \multicolumn{1}{c}{ Classification* } & NDVI value* & Area (ha) \\
\hline Rare & $0-0.33$ & 0.387 \\
Moderate & $0.33-0.43$ & 0.523 \\
Dense & $0.43-1$ & 202.758 \\
Total & \multicolumn{2}{c}{203.668} \\
\hline
\end{tabular}

Note: *NDVI value classification according to Indonesia Forestry Department (2005)

\section{Aboveground living biomass and aboveground living biomass carbon stock}

Aboveground living biomass accounts for $21 \%$ of the mangrove ecosystem's total carbon stock (Howard et al. 2014). Data of DBH measurement were used as an input for biomass allometric equation based on earlier studies as shown in Table 1. Table 3 shows aboveground living biomass in terms of total biomass from trees and saplings.

This study used a carbon conversion factor to determine carbon stock from aboveground living biomass, resulting in a perfect correlation between aboveground living biomass and aboveground living biomass carbon stock. According to Table 3 , the highest aboveground living biomass and carbon stock were found in Station 4, which is dominated by $S$. alba; in this station, a large tree of $S$. alba with $\mathrm{DBH}$ $47.23 \mathrm{~cm}$ was found. Based on Figure 4, $S$. alba was the 
second-largest mean DBH among other species found in the study area. Figure 4 shows that the largest mean DBH belonged to $B$. cylindrica, followed by $S$. alba, A. alba, A. marina var. rumphiana, and $R$. apiculata. In contrast, the smallest mean DBH was of $C$. tagal which dominated the stand density of station 2. Regardless of that, high stand density was found in station 2, but it had low aboveground living biomass. The Mangrove community dominated by small trees is reported to have higher stand density while the community dominated by large trees are reported to have lower stand density (Kamruzzaman et al. 2017). Stand density is the factor to differentiate early growth of mangrove, young stand (sapling) to mature stand (tree) by reducing the number of stands (Fromard et al. 1998).

According to Table 3, the average aboveground living biomass was $121.58 \pm 109.78 \mathrm{Mg} \mathrm{ha}^{-1}$, and it ranged from $62.19 \mathrm{Mg} \mathrm{ha}^{-1}$ (station 1) to $271.78 \mathrm{Mg} \mathrm{ha}^{-1}$ (station 4) This study observed higher aboveground living biomass than previous study of Kusumaningtyas et al. (2014) at mangrove forest in Nusa Lembongan, which reported $114.73 \mathrm{Mg} \mathrm{ha}^{-1}$. However, the average aboveground living biomass carbon stock was $56.41 \pm 50.94 \mathrm{Mg} \mathrm{C}^{-1}$ ranged from $28.85 \pm 20.20 \mathrm{Mg} \mathrm{C}^{-1}$ (station 1) up to $126.11 \pm$ 74.57 (station 4) $\mathrm{Mg} \mathrm{C} \mathrm{ha}^{-1}$. This study had lower result of average living biomass carbon stock compared to the previous study by Kusumaningtyas et al. (2014) in Nusa Lembongan, which resulted in 59.95 $\mathrm{Mg} \mathrm{C} \mathrm{ha}^{-1}$.

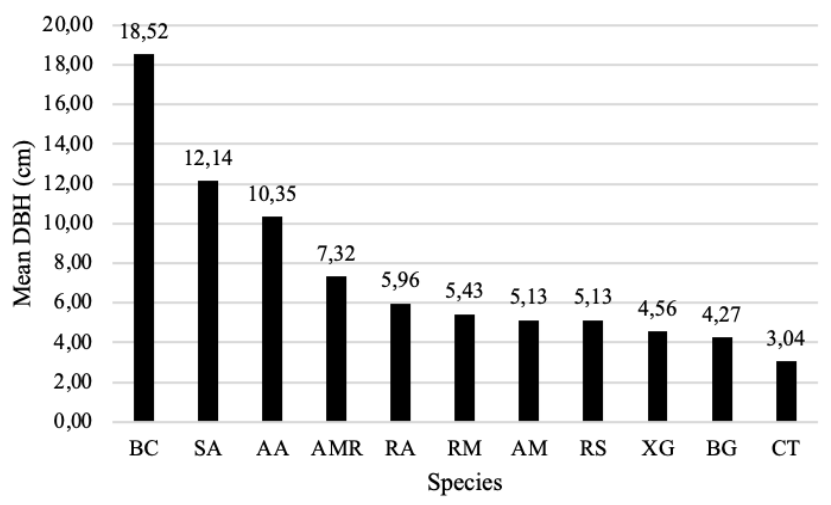

Figure 4. Mean DBH of species found in study area

Table 3. Aboveground living biomass and carbon stock in each observation station of mangrove forest of Nusa Lembongan, Bali Province, Indonesia

\begin{tabular}{|c|c|c|c|c|}
\hline Station & Species & $\begin{array}{l}\text { Total aboveground } \\
\text { living biomass }(\mathbf{k g})\end{array}$ & $\begin{array}{l}\text { Total aboveground living } \\
\text { biomass }\left(\mathrm{Mg} \mathrm{ha}^{-1}\right)\end{array}$ & $\begin{array}{c}\text { Aboveground living } \\
\text { biomass carbon stock } \\
\left(\mathrm{Mg} \mathrm{C} \mathrm{ha}^{-1}\right)\end{array}$ \\
\hline 1 & $\begin{array}{l}\text { A. marina } \\
\text { R. mucronata } \\
\text { A. alba } \\
\text { R. apiculata } \\
\text { Rhizophora stylosa } \\
\text { B. gymnorhiza } \\
\text { Total }\end{array}$ & \begin{tabular}{r|}
497.61 \\
1454.05 \\
125.80 \\
1586.94 \\
58.79 \\
8.00 \\
$\mathbf{3 7 3 1 . 1 9}$
\end{tabular} & 62.19 & $28.85 \pm 20.20$ \\
\hline 2 & $\begin{array}{l}\text { R. mucronata } \\
\text { C. tagal } \\
\text { R. apiculata } \\
\text { A. marina } \\
\text { X. granatum } \\
\text { Rhizophora stylosa } \\
\text { A. marina var. rumphiana } \\
\text { Total }\end{array}$ & $\begin{array}{r}2763.03 \\
488.89 \\
35.90 \\
151.16 \\
317.89 \\
25.68 \\
22.32 \\
\mathbf{3 8 0 4 . 8 6}\end{array}$ & 63.41 & $29.42 \pm 14.21$ \\
\hline 3 & $\begin{array}{l}\text { R. apiculata } \\
\text { R. mucronata } \\
R \text {. stylosa } \\
X . \text { granatum } \\
\text { S. alba } \\
\text { Total }\end{array}$ & $\begin{array}{r}3075.04 \\
831.28 \\
15.01 \\
417.67 \\
58.35 \\
\mathbf{4 3 9 7 . 3 6}\end{array}$ & 73.29 & $34.01 \pm 15.30$ \\
\hline 4 & $\begin{array}{l}\text { R. mucronata } \\
\text { R. apiculata } \\
\text { S. alba } \\
\text { B. gymnorhiza } \\
\text { B. cylindrica } \\
\text { Total }\end{array}$ & $\begin{array}{r}4626.53 \\
2339.64 \\
8297.57 \\
3.23 \\
1039.76 \\
\mathbf{1 6 3 0 6 . 7 4}\end{array}$ & 271.78 & $126.11 \pm 74.57$ \\
\hline 5 & $\begin{array}{l}R . \text { apiculata } \\
R . \text { mucronata } \\
\text { Total }\end{array}$ & $\begin{array}{r}8083.34 \\
151.56 \\
\mathbf{8 2 3 4 . 8 9}\end{array}$ & 137.25 & $63.68 \pm 19.13$ \\
\hline
\end{tabular}




\section{Soil properties and soil carbon stock}

Soil properties include bulk density, water content, \%C, $\% \mathrm{~N}, \mathrm{C}: \mathrm{N}$ ratio and particle size, were analyzed in each station. Few studies argue that soil properties can be a significant predictor of carbon storage in coastal landscape, as most of the carbon in a coastal ecosystem are stored in the soils (Prasad et al. 2010; Lunstrum and Chen 2014; Matsui et al. 2015; Dahl et al. 2016; Wang et al. 2016). Table 4 shows the mean value \pm SD of each property for the depth profiles $0-30 \mathrm{~cm}$ in all stations.

In general, the mean value of soil carbon stock in mangrove forest Nusa Lembongan in $30 \mathrm{~cm}$ depth was $79.79 \pm 23.02 \mathrm{Mg} \mathrm{C}^{-1}$. The soil carbon stock results in each station as shown in Table 4 did not differ significantly. This value can be greater as the common depth used to measure soil carbon stock in topsoil was $1 \mathrm{~m}$ (Howard et al. 2014). Therefore, bulk density and \%C data were used as an approach to compare carbon stock in this study with other studies. The mean value of bulk density in this study was $1.10 \pm 0.11 \mathrm{~g} \mathrm{~cm}^{-3}$, this was higher compared to mangrove soils in Bintuni Bay $(0.3 \pm 0.1 \mathrm{~g}$ $\mathrm{cm}^{-3}$ to $0.9 \pm 0.1 \mathrm{~g} \mathrm{~cm}^{-3}$ ) (Sasmito et al. 2020b) and Segara Anakan $\left(0.69 \pm 0.12 \mathrm{~g} \mathrm{~cm}^{-3}\right)$ but lower compared to mangrove soils in Berau $\left(1.20 \pm 0.36 \mathrm{~g} \mathrm{~cm}^{-3}\right)$ and Kongsi Island $\left(1.35 \pm 0.18 \mathrm{~g} \mathrm{~cm}^{-3}\right)$ (Kusumaningtyas et al. 2019). The highest bulk density was found in station 3; meanwhile, the lowest bulk density was found in station 4 . The mean value of $\% \mathrm{C}$ in Central Segara Anakan was $2.4 \pm$ $0.8 \%$ which has a similar result compared to this study $(2.47 \pm 0.99 \%)$ (Kusumaningtyas et al. 2019). However, this study revealed a lower \% C compared to Berau (5.7 \pm 3.7\%) (Kusumaningtyas et al. 2019) and Bintuni Bay (16.4 $\pm 2.1 \%$ ) (Sasmito et al. 2020b) and higher \%C compared to Kongsi Island $(0.8 \pm 0.2 \%)$ (Kusumaningtyas et al. 2019).

Carbon sequestration in soils is more complicated than in biomass because the source of carbon does not come only from the vegetation itself but also from outside the system. Autochthonous carbon comes from its system; carbon is produced from $\mathrm{CO}_{2}$ intake in mangrove biomass and associated biota and stored in mangrove soils (Howard et al. 2014; Saderne et al. 2019). Meanwhile, allochthonous carbon comes from outside the system; this carbon is produced from other places, in the context of blue carbon, carbon that comes from land or other marine ecosystems such as seagrass and coral reef ecosystem (Howard et al. 2014). C:N ratio were used to identify the source of carbon in sediment; in this study, the value of C:N ranged from 10 to 27, which was close to the result from a study in Kongsi Island $(20.8 \pm 0.6)$ but lower compared to marine mangrove in Segara Anakan (28.55 up to 64.36) (Weiss et al. 2016; Kusumaningtyas et al. 2019). C:N ratio of mangrove biomass known to be around 32.6 up to 298 (Weiss et al. 2016; Sasmito et al. 2020a). It can be considered that the source of carbon in this study was from allochthonous carbon, since $\mathrm{C}: \mathrm{N}$ ratio found in soil was far from the ratio in mangrove biomass. However, it can also imply high decomposition rates due to the low residence time of water that increases exposure time to oxygen, promoting decomposition (Ranjan et al. 2011).

According to Table 4, the highest soil carbon stock were found in station 5 with $81.88 \pm 28.89 \mathrm{Mg} \mathrm{C} \mathrm{ha}^{-1}$ followed with station $2\left(80.12 \pm 24.80 \mathrm{Mg} \mathrm{C}^{-1}\right)$, station 4 $\left(79.59 \pm 16.93 \mathrm{Mg} \mathrm{C}^{-1} \mathrm{ar}^{-1}\right)$, station $1(78.73 \pm 39.92 \mathrm{Mg} \mathrm{C}$ $\left.\mathrm{ha}^{-1}\right)$, and the least is station $3\left(78.66 \pm 19.17 \mathrm{Mg} \mathrm{C} \mathrm{ha}^{-1}\right)$. Based on Pearson's correlation analysis, it shows correlation between \% $\mathrm{C}$ with bulk density $(\mathrm{r}=-0.406$; $\mathrm{p}<$ $0.01)$ and significance correlation with $\% \mathrm{~N}(\mathrm{r}=0.922 ; \mathrm{p}<$ 0.05 ). This result is supported by few studies that also show an inverse relationship between $\% \mathrm{C}$ and bulk density (Avnimelech et al. 2001; Stringer et al. 2016; Gao et al. 2019). Bulk density can restrain natural root growth, and a bulk density of $\leq 1.3 \mathrm{~g} \mathrm{~cm}^{-3}$ is reported to be good, between $1.3-1.55 \mathrm{~g} \mathrm{~cm}^{-3}$ to be moderate, and $\geq 1.8 \mathrm{~g} \mathrm{~cm}^{-3}$ is reported to be extremely bad (Mukhopadhyay et al. 2019). A positive correlation between $\% \mathrm{C}$ and $\% \mathrm{~N}$ was also found in a study conducted by Huang et al. (2018).

\section{Total carbon stock}

Based on this study the total carbon stock (aboveground living biomass and soil) in station 1,2, 3, 4 and 5 were $53.79 \pm 39.85 \mathrm{Mg} \mathrm{C}^{-1} ; 54.77 \pm 32.75 \mathrm{Mg} \mathrm{C}^{-1} ; 56.33 \pm$ $28.59 \mathrm{Mg} \mathrm{C}^{-1} ; 85.56 \pm 51.93 \mathrm{Mg} \mathrm{C}^{-1} ; 72.78 \pm 25.17$ $\mathrm{Mg} \mathrm{C} \mathrm{ha}^{-1}$ respectively as shown in Figure 5. The highest total carbon stock was found in station 4 and the lowest was found in station 1, these results corroborate data in Table 3 which also shows the highest aboveground living biomass carbon stock was found in station 4 and the lowest was found in station 1 .

Table 4. Soil properties and soil carbon stock in each observation station of mangrove forest Nusa Lembongan, Bali Province, Indonesia

\begin{tabular}{|c|c|c|c|c|c|}
\hline \multirow{2}{*}{ Properties } & \multicolumn{5}{|c|}{ Station } \\
\hline & 1 & 2 & 3 & 4 & 5 \\
\hline Water content $(\%)$ & $37.94 \pm 3.88$ & $32.85 \pm 4.25$ & $23.84 \pm 3.17$ & $37.42 \pm 7.69$ & $37.56 \pm 8.89$ \\
\hline Bulk density $\left(\mathrm{g} \mathrm{cm}^{-3}\right)$ & $1.09 \pm 0.03$ & $1.12 \pm 0.08$ & $1.15 \pm 0.16$ & $1.05 \pm 0.08$ & $1.06 \pm 0.14$ \\
\hline$\% \mathrm{C}$ & $2.39 \pm 1.08$ & $2.42 \pm 0.93$ & $2.30 \pm 0.64$ & $2.53 \pm 0.48$ & $2.70 \pm 1.71$ \\
\hline$\% \mathrm{~N}$ & $0.14 \pm 0.03$ & $0.13 \pm 0.03$ & $0.13 \pm 0.01$ & $0.12 \pm 0.01$ & $0.13 \pm 0.05$ \\
\hline $\mathrm{C}: \mathrm{N}$ & $16.83 \pm 3.87$ & $18.67 \pm 4.72$ & $17.33 \pm 3.33$ & $20.50 \pm 2.51$ & $20.50 \pm 3.39$ \\
\hline$\%$ Sand (particle size $2-0.05 \mathrm{~mm}$ ) & $34.60 \pm 9.03$ & $42.60 \pm 17.78$ & $60.67 \pm 25.79$ & $83.38 \pm 4.07$ & $62.72 \pm 9.06$ \\
\hline$\%$ Silt (particle size $50-2 \mu \mathrm{m}$ ) & $53.40 \pm 11.14$ & $47.22 \pm 15.34$ & $31.25 \pm 21.76$ & $12.55 \pm 4.03$ & $29.82 \pm 7.81$ \\
\hline$\%$ Clay (particle size $<2 \mu \mathrm{m}$ ) & $12.20 \pm 5.62$ & $10.18 \pm 4.23$ & $8.05 \pm 5.99$ & $4.07 \pm 0.98$ & $7.43 \pm 2.92$ \\
\hline Soil carbon stock $\left(\mathrm{Mg} \mathrm{C} \mathrm{ha-1}^{-1}\right)$ & $78.73 \pm 39.92$ & $80.12 \pm 24.80$ & $78.66 \pm 19.17$ & $79.59 \pm 16.93$ & $81.88 \pm 28.89$ \\
\hline
\end{tabular}




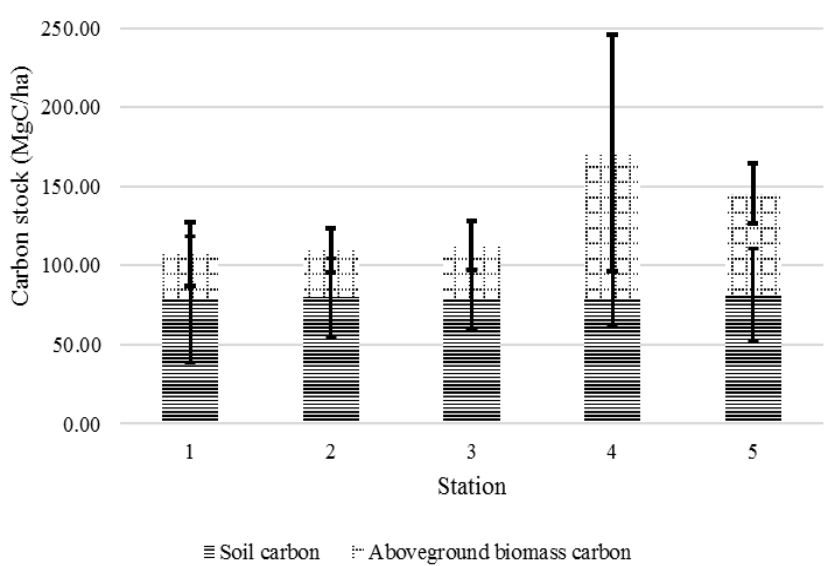

Figure 5. Total carbon stock in soil and aboveground living biomass

This study found that the contribution of aboveground living biomass to total carbon stock was $38 \%$. According to Figure 5, most carbons were stored in the soil, which accounts for $64 \%$ of total carbon stock. This observation is quite close to a previous study that states $77 \%$ of total carbon stock in the mangrove ecosystem was stored in soil (Alongi 2020; Kauffman et al. 2014; Sasmito et al. 2020b). Coastal ecosystem are known to have higher carbon accumulation in sediments/soil compared to terrestrial vegetation mainly because of high autochthonous and allochthonous inputs and low decomposition rates of organic matter due to the mostly anoxic conditions in the sediment (Kristensen 2000; Donato et al. 2011; Kida and Fujitake 2020). The rate of organic carbon accumulation in mangrove ecosystems is estimated to be around $20-24 \mathrm{Tg}$ C $\mathrm{yr}^{-1}$ (Twilley et al. 1992; Jennerjahn et al. 2004). However, in station 4 the contribution of aboveground living biomass to total carbon stock was $61 \%$ because the site was dominated by old trees with high $\mathrm{DBH}$ from species such as $S$. alba and B. cylindrica as shown in Figure 4.

The result of multiple regression analysis shows a significant association between total carbon stock with water content, bulk density, \%N, \%C, \%Clay, stand density and aboveground living biomass simultaneously $\left(\mathrm{R}^{2}=\right.$ 0.997). However, only $\% \mathrm{~N}, \% \mathrm{C}$, and aboveground living biomass have a significant relationship with total carbon stock ( $p<0.05)$. A previous study by Sasmito et al. (2020b) found a strong influence between bulk density, carbon content and basal area with total stock carbon. It can be considered that this study contradicts the statement regarding bulk density but supports the influence of carbon content and basal area on total stock carbon. Basal area and aboveground living biomass are correlated as both are related to trunk diameter (Torres and Lovett 2013).

In conclusion, the total carbon stock from aboveground biomass and soil of mangrove forest Nusa Lembongan was $68.10 \pm 20.92 \mathrm{Mg} \mathrm{C} \mathrm{ha}^{-1}$ and equals to $249.95 \pm 76.77$ $\mathrm{MgCO}_{2} \mathrm{ha}^{-1}$, with significant carbon stocks were stored in the soil. Nevertheless, in station 4, the aboveground living biomass stored significant carbon compared to the soil as seen on Table 3 , station 4 had the highest aboveground living biomass, Therefore, it is important to protect mangrove forest especially those which dominated by old and large trees and avoid degradation because it has stored great amount of carbon. The essential parameters that can promote carbon sequestration in mangrove forest Nusa Lembongan were aboveground living biomass, soil organic carbon content, and soil organic nitrogen content. Besides, as soil organic carbon content also negatively correlates with bulk density, it also can be considered.

\section{ACKNOWLEDGEMENTS}

This study was supported by School of Environmental Science, Universitas Indonesia, Depok with Hibah Internal Sekolah Ilmu Lingkungan 2021. This research under supervision from Cluster of Interaction, Community Engagement and Social Environment, School of Environmental Science, Universitas Indonesia (https://social.sil.ui.ac.id). We would like to express our great appreciation to Jungutbatu village community, Klungkung District Government, Forest Management Unit of Bali Selatan, and Technical Implementation Unit of Bali Marine Protected Area for giving us permission to conduct our research in mangrove forest of Nusa Lembongan and offering help that we need. We also would like to thank the field sampling team who helped us a lot.

\section{REFERENCES}

Alongi DM. 2020. Carbon balance in salt marsh and mangrove ecosystems: A global synthesis. J Mar Sci Eng 8 (10): 767. DOI: 10.3390/jmse8100767.

American Society of Agronomy and Soil Science Society of America. 1982. Methods of Soil Analysis, $2^{\text {nd }}$ ed. In: Page et al. (eds) Chemical and Microbiological Properties. American Society of Agronomy, Inc. and Soil Science Society of America, Inc. Wisconsin, USA.

Anwar S. 2020. The potential role of blue carbon in REDD+ and NDC [PowerPoint Presentation]. Directorate General of Climate Change Control, Jakarta.

Asadi MA, Yona D, Saputro SE. 2018. Species Diversity, Biomass, and Carbon Stock Assessments of Mangrove Forest in Labuhan, Indonesia. IOP Conf Ser Earth Environ Sci 151 (1): 012009. DOI: $10.1088 / 1755-1315 / 151 / 1 / 012009$

Avnimelech Y, Ritvo G, Meijer LE, Kochba M. 2001. Water content, organic carbon and dry bulk density in flooded sediments. Aquac Eng 25 (1): 25-33. DOI: 10.1016/S0144-8609(01)00068-1.

Barreto MB, Lo Mónaco S, Díaz R, Barreto-Pittol E, López L, Peralba M do CR. 2016. Soil organic carbon of mangrove forests (Rhizophora and Avicennia) of the Venezuelan Caribbean coast. Org Geochem 100: 51-61. DOI: 10.1016/j.orggeochem.2016.08.002.

Bengen DG. 2000. Pedoman Teknis Pengenalan dan Pengelolaan Ekosistem Mangrove. Pusat Kajian Sumber Daya Pesisir dan Lautan, Institut Pertanian Bogor, Bogor. [Indonesian]

Breithaupt JL, Smoak JM, Smith TJ, Sanders CJ, Hoare A. 2012. Organic carbon burial rates in mangrove sediments: Strengthening the global budget. Global Biogeochem Cycles 26 (3): GB3011. DOI: 10.1029/2012GB004375.

Clough BF, Scott K. 1989. Allometric relationships for estimating aboveground biomass in six mangrove species. For Ecol Manag 27 (2): 117-127. DOI: 10.1016/0378-1127(89)90034-0. 
Comley BWT, McGuinness KA. 2005. Above- and below-ground biomass, and allometry, of four common northern Australian mangroves. Aust J Bot 53 (5): 431-436. DOI: 10.1071/BT04162.

Dahl M, Deyanova D, Gütschow S, Asplund ME, Lyimo LD, Karamfilov V, Santos R, Björk M, Gullström M. 2016. Sediment properties as important predictors of carbon storage in Zostera marina meadows: A comparison of four European areas. PLoS One 11 (12): e0167493. DOI: 10.1371/journal.pone.0167493.

Daulat A, Pranowo WS, Amri SN. 2018. Mangrove forest change in Nusa Penida Marine Protected Area, Bali-Indonesia using Landsat satellite imagery. Int J Remote Sens Earth Sci 15 (2): 141-156. DOI: 10.30536/j.ijreses.2018.v15.a2955.

Donato DC, Kauffman JB, Murdiyarso D, Kurnianto S, Stidham M, Kanninen M. 2011. Mangroves among the most carbon-rich forests in the tropics. Nat Geosci 4 (5): 293-297. DOI: 10.1038/ngeo1123.

Estrada GCD, Soares MLG. 2017. Global patterns of aboveground carbon stock and sequestration in mangroves. An Acad Bras Cienc 89 (2) 973-989. DOI: 10.1590/0001-3765201720160357.

Friess DA, Rogers K, Lovelock CE, Krauss KW, Hamilton SE, Lee SY, Lucas R, Primavera J, Rajkaran A, Suhua Shi S. 2019. The State of the World's Mangrove Forests: Past, Present, and Future. Ann Rev Environ Resour 44: 89-115. DOI: 10.1146/annurev-environ-101718033302 .

Fromard F, Puig H, Mougin E, Marty G, Betoulle JL, Cadamuro L. 1998. Structure, above-ground biomass and dynamics of mangrove ecosystems: New data from French Guiana. Oecologia 115 (1-2): 3953. DOI: $10.1007 / \mathrm{s} 004420050489$.

Gao Y, Zhou J, Wang L, Guo J, Feng J, Wu H, Lin G. 2019. Distribution patterns and controlling factors for the soil organic carbon in four mangrove forests of China. Glob Ecol Conserv 17: e00575. DOI 10.1016/j.gecco.2019.e00575.

Gevana DT, Im S. 2016. Allometric models for Rhizophora stylosa griff. in dense monoculture plantation in the Philippines. Malaysian For 79 (1-2): 39-53

Grace J, José JS, Meir P, Miranda HS, Montes RA. 2006. Productivity and carbon fluxes of tropical savannas. J Biogeogr 33 (3): 387-400. DOI: 10.1111/j.1365-2699.2005.01448.x.

Hamilton SE, Casey D. 2016. Creation of a high spatio-temporal resolution global database of continuous mangrove forest cover for the 21st century (CGMFC-21). Glob Ecol Biogeogr 25 (6): 729-738. DOI: $10.1111 /$ geb.12449.

Howard J, Hoyt S, Isensee K, Telszewski M, Pidgeon E. 2014. Coastal Blue Carbon: Methods for assessing carbon stocks and emissions factors in mangroves, tidal salt marshes, and seagrasses. Conservation International, Intergovernmental Oceanographic Commission of UNESCO, International Union for Conservation of Nature. Arlington, Virginia, USA

Howard J, McLeod E, Thomas S, Eastwood E, Fox M, Wenzel L, Pidgeon E. 2017. The potential to integrate blue carbon into MPA design and management. Aquat Conserv Mar Freshw Ecosyst 27: 100-115. DOI: $10.1002 /$ aqc. 2809

Huang X, Wang X, Li X, Xin K, Yan Z, Sun Y, Bellerby R. 2018 Distribution pattern and influencing factors for soil organic carbon (SOC) in mangrove communities at Dongzhaigang, China. J Coast Res 34 (2): 434-442. DOI: 10.2112/JCOASTRES-D-16-00207.1.

Indonesia Forestry Department. 2005. Pedoman Inventarisasi dan Identifikasi Lahan Kritis Mangrove. Jakarta. [Indonesian]

Ishchenko V. 2018. Prediction of heavy metals concentration in the leachate: A case study of Ukrainian waste. J Mater Cycles Waste Manag 20 (3):1892-1900. DOI: 10.1007/s10163-018-0740-7

Jennerjahn TC, Ittekkot V, Klöpper S, Adi S, Purwo Nugroho S, Sudiana N, Yusmal A, Prihartanto, Gaye-Haake B. 2004. Biogeochemistry of a tropical river affected by human activities in its catchment: Brantas River estuary and coastal waters of Madura Strait, Java, Indonesia. $\begin{array}{lllll}\text { Estuar Coast Shelf Sci } 60 & \text { (3): 503-514. DOI }\end{array}$ 10.1016/j.ecss.2004.02.008.

Kamruzzaman M, Ahmed S, Osawa A. 2017. Biomass and net primary productivity of mangrove communities along the Oligohaline zone of Sundarbans, Bangladesh. For Ecosyst 4 (1): $16 . \quad$ DOI 10.1186/s40663-017-0104-0.

Kangkuso A, Sharma S, Jamili J, Septiana A, Sahidin I, Rianse U, Rahim S, Nadaoka K. 2018. Trends in allometric models and aboveground biomass of family Rhizophoraceae mangroves in the Coral Triangle ecoregion, Southeast Sulawesi, Indonesia. J Sustain For 37 (7): 691711. DOI: $10.1080 / 10549811.2018 .1453843$.
Kanmani S, Gandhimathi R. 2013. Assessment of heavy metal contamination in soil due to leachate migration from an open dumping site. Appl Water Sci 3 (1): 193-205. DOI: 10.1007/s13201012-0072-z

Kauffman JB, Donato DC. 2012. Protocols for the measurement, monitoring and reporting of structure, biomass and carbon stocks in mangrove forests. Bogor Report, Bogor.

Kauffman JB, Heider C, Norfolk J, Payton F. 2014. Carbon stocks of intact mangroves and carbon emissions arising from their conversion in the Dominican Republic. Ecol Appl 24 (3): 518-527. DOI: 10.1890/13-0640.1.

Kida M, Fujitake N. 2020. Organic carbon stabilization mechanisms in mangrove soils: A review. Forests 11 (9): 981. DOI: 10.3390/f11090981.

Komiyama A, Poungparn S, Kato S. 2005. Common allometric equations for estimating the tree weight of mangroves. J Trop Ecol 21 (4): 471477. DOI: $10.1017 /$ S0266467405002476.

Kristensen E. 2000. Organic matter diagenesis at the oxic/anoxic interface in coastal marine sediments, with emphasis on the role of burrowing animals. Hydrobiologia 426 (1): 1-24. DOI: 10.1023/A:1003980226194.

Kusmana C, Hidayat T, Tiryana T, Rusdiana O, Istomo. 2018. Allometric models for above- and below-ground biomass of Sonneratia spp. Glob Ecol Conserv.15: e00417. DOI: 10.1016/j.gecco.2018.e00417.

Kusumaningtyas MA, Daulat A, Suryono DD, Restu NAA, Kepel TL, Rustam A, et al. 2014. Blue carbon stock of mangrove ecosystem in Nusa Penida, Bali. In: The 12th Biennial Conference of Pan Ocean Remote Sensing Conference (PORSEC 2014). Denpasar.

Kusumaningtyas MA, Hutahaean AA, Fischer HW, Pérez-Mayo M, Ransby D, Jennerjahn TC. 2019. Variability in the organic carbon stocks, sources, and accumulation rates of Indonesian mangrove ecosystems. Estuar Coast Shelf Sci 218: 310-323. DOI: 10.1016/j.ecss.2018.12.007.

Lewis SL, Lloyd J, Sitch S, Mitchard ETA, Laurance WF. 2009. Changing Ecology of Tropical Forests: Evidence and Drivers. Annu Rev Ecol Evol Syst 40 (1): 529-549. DOI: 10.1146/annurev.ecolsys.39.110707.173345.

Lovelock CE, Duarte CM. 2019. Dimensions of blue carbon and emerging $\begin{array}{llllll}\text { perspectives. Biol Lett } 15 & \text { (3): 20180781. DOI: }\end{array}$ 10.1098/rsbl.2018.0781.

Lovelock CE, Feller IC, McKee KL, Thompson R. 2005. Variation in mangrove forest structure and sediment characteristics in Bocas del Toro, Panama. Caribbean J Sci 41 (3): 456-464.

Lunstrum A, Chen L. 2014. Soil carbon stocks and accumulation in young mangrove forests. Soil Biol Biochem 75: 223-232. DOI: 10.1016/j.soilbio.2014.04.008.

Macreadie PI, Anton A, Raven JA, Beaumont N, Connolly RM, Friess DA, et al. 2019. The future of blue carbon science. Nat Commun 10 (1): 3998. DOI: 10.1038/s41467-019-11693-w.

Martuti NKT, Setyowati DL, Nugraha SB, Mutiatari DP. 2017. Carbon stock potency of mangrove ecosystem at Tapak Sub-village, Semarang, Indonesia. AACL Bioflux 10 (6): 1524-1533.

Mather PM, Koch M. 2011. Computer Processing of Remotely-sensed Images: An Introduction. 4th ed. Oxford: John Wiley \& Sons. DOI: $10.1002 / 9780470666517$

Matsui N, Meepol W, Chukwamdee J. 2015. Soil organic carbon in mangrove ecosystems with different vegetation and sedimentological conditions. J Mar Sci Eng 3 (4): 1404-1424. DOI: 10.3390/jmse3041404.

McLeod E, Chmura GL, Bouillon S, Salm R, Björk M, Duarte CM, Lovelock CE, Schlesinge WH, Silliman BR. 2011. A blueprint for blue carbon: Toward an improved understanding of the role of vegetated coastal habitats in sequestering $\mathrm{CO}_{2}$. Front Ecol Environ 9 (10): 552-560. DOI: 10.1890/110004.

Mukhopadhyay S, Masto RE, Tripathi RC, Srivastava NK. 2019. Application of Soil Quality Indicators for the Phytorestoration of Mine Spoil Dumps. In: Pandey VC, Bauddh (eds) Phytomanagement of Polluted Sites, Elsevier Inc. DOI: 10.1016/B978-0-12-8139127.00014-4.

Nguyen LTM, Hoang HT, Van Ta H, Park PS. 2020. Comparison of mangrove stand development on accretion and erosion sites in $\mathrm{Ca}$ Mau, Vietnam. Forests 11 (6): 615. DOI: 10.3390/F11060615.

Palguna IBA, Ardhana IP, Arthana IW. 2017. Struktur dan keanekaragaman jenis mangrove di kawasan hutan mangrove Nusa Lembongan, Kecamatan Nusa Penida, Kabupaten Klungkung. Ecotrophic 11 (2): 108-115. [Indonesian] 
Pérez A, Libardoni BG, Sanders CJ. 2018. Factors influencing organic carbon accumulation in mangrove ecosystems. Biol Lett 14 (10) 20180237. DOI: 10.1098/rsbl.2018.0237.

Prasad MBK, Dittmar T, Ramanathan AL. 2010. Organic matter and mangrove productivity. In: Ramanathan AL, Bhattacharya P, Dittmar T, Prasad MBK, Neupane BR. (eds) Management and Sustainable Development of Coastal Zone Environments, Springer, Dordrecht. DOI: 10.1007/978-90-481-3068-9_12.

Ranjan RK, Routh J, Ramanathan AL, Klump JV. 2011. Elemental and stable isotope records of organic matter input and its fate in the Pichavaram mangrove-estuarine sediments (Tamil Nadu, India). Mar Chem 126 (1-4): 163-172. DOI: 10.1016/j.marchem.2011.05.005.

Saderne V, Geraldi NR, Macreadie PI, Maher DT, Middelburg JJ, Serrano O, et al. 2019. Role of carbonate burial in Blue Carbon budgets. Nat Commun 10 (1). 1106. DOI: 10.1038/s41467-019-08842-6.

Sasmito SD, Kuzyakov Y, Lubis AA, Murdiyarso D, Hutley LB, Bachri S, Friess DA, Martius C, Borchard N. 2020a. Organic carbon burial and sources in soils of coastal mudflat and mangrove ecosystems. Catena 187: 104414. DOI: 10.1016/j.catena.2019.104414.

Sasmito SD, Sillanpää M, Hayes MA, Bachri S, Saragi-Sasmito MF, Sidik F, et al. 2020b. Mangrove blue carbon stocks and dynamics are controlled by hydrogeomorphic settings and land-use change. Glob Chang Biol 26 (5): 3028-3039. DOI: 10.1111/gcb.15056.

Satyanarayana B, Mohamad KA, Idris IF, Husain ML, Dahdouh-Guebas F. 2011. Assessment of mangrove vegetation based on remote sensing and ground-truth measurements at Tumpat, Kelantan Delta, Eas Coast of Peninsular Malaysia. Intl J Remote Sens 32 (6): 1635-1650. DOI: $10.1080 / 01431160903586781$.

Soerianegara I, Indrawan A. 1988. Ekologi Hutan Indonesia. Fakultas Kehutanan IPB, Bogor. [Indonesian]

Stringer CE, Trettin CC, Zarnoch SJ. 2016. Soil properties of mangroves in contrasting geomorphic settings within the Zambezi River Delta, Mozambique. Wetlands Ecol Manag 24 (2): 139-152. DOI: 10.1007/s11273-015-9478-3.
Suryono S, Soenardjo N, Wibowo E, Ario R, Rozy EF. 2018. Estimasi kandungan biomassa dan karbon di Hutan Mangrove Perancak Kabupaten Jembrana, Provinsi Bali. Bul Oseanografi Mar 7 (1): 1. DOI: 10.14710/buloma.v7i1.19036. [Indonesian]

Taillardat P, Friess DA, Lupascu M. 2018. Mangrove blue carbon strategies for climate change mitigation are most effective at the national scale. Biol Lett 14 (10): 20180251. DOI: 10.1098/rsbl.2018.0251.

Tan KH. 2005. Soil sampling, preparation, and analysis. 2nd ed. Taylor \& Francis, Boca Raton, FL.

Torres AB, Lovett JC. 2013. Using basal area to estimate aboveground carbon stocks in forests: La Primavera Biosphere's Reserve, Mexico. Forestry 86 (2): 267-281. DOI: 10.1093/forestry/cps084

Twilley RR, Chen RH, Hargis T. 1992. Carbon sinks in mangroves and their implications to carbon budget of tropical coastal ecosystems. Water, Air, Soil Pollut 64 (1-2): 265-288. DOI: 10.1007/BF00477106.

Wang J, Bai J, Zhao Q, Lu Q, Xia Z. 2016. Five-year changes in soil organic carbon and total nitrogen in coastal wetlands affected by flow-sediment regulation in a Chinese delta. Sci Rep 6: 21137. DOI: $10.1038 /$ srep21137.

Weiss C, Weiss J, Boy J, Iskandar I, Mikutta R, Guggenberger G. 2016. Soil organic carbon stocks in estuarine and marine mangrove ecosystems are driven by nutrient colimitation of $\mathrm{P}$ and N. Ecol Evol 6 (14): 5043-5056. DOI: 0.1002/ece3.2258.

Welly M, Sanjaya W, Sumerta IN, Anom DN. 2010. Identifikasi flora dan fauna mangrove Nusa Lembongan dan Nusa Ceningan. January 2017: 1-14. [Indonesian]

Worthington TA, Andradi-Brown DA, Bhargava R, Buelow C, Bunting P, Duncan C, et al. 2020. Harnessing Big Data to support the conservation and rehabilitation of Mangrove Forests globally. One Earth 2 (5): 429-443. DOI:10.1016/j.oneear.2020.04.018. 